\title{
Characterization of Bottom Ash Waste Adsorbent from Palm Oil Plant Boiler Burning Process to Adsorb Carbon Dioxide in a Fixed Bed Column
}

\author{
Novi Sylvia ${ }^{1,2}$, Fitriani Fitriani ${ }^{2}$, Rozanna Dewi ${ }^{2}$, Rizka Mulyawan $^{2}$, Abrar Muslim $^{3}$, Husni Husin ${ }^{3}$, \\ Yunardi Yunardi ${ }^{*}$, and Mutia Reza ${ }^{4}$ \\ ${ }^{1}$ Doctoral Program, School of Engineering, Post Graduate Program, Universitas Syiah Kuala, Banda Aceh 23111, Indonesia \\ ${ }^{2}$ Department of Chemical Engineering, Malikussaleh University, Lhokseumawe, 24351, Indonesia \\ ${ }^{3}$ Department of Chemical Engineering, Universitas Syiah Kuala, Banda Aceh 23111, Indonesia \\ ${ }^{4}$ Department of Chemical Engineering, Institut Teknologi Kalimantan, Indonesia
}

\section{* Corresponding author: \\ email: yunardi@unsyiah.ac.id}

Received: June 10, 2021

Accepted: September 18, 2021

DOI: $10.22146 /$ ijc. 66509

\begin{abstract}
Palm oil bottom ash utilization from mill boilers as $\mathrm{CO}_{2}$ adsorbent has been in use for few years. This study aims to examine adsorbent characteristics and capabilities of bottom ash produced from boiler combustion in palm oil industry for $\mathrm{CO}_{2}$ adsorption before and after utilization, such as compound functional group using the Fourier Transform Infra-Red (FT-IR) spectrophotometer, adsorbent morphology through Scanning Electron Microscopy (SEM), and compound amount using Energy Dispersive $X$-Ray Spectroscopy (EDX). The $\mathrm{CO}_{2}$ adsorption was carried out in fixed-bed column. Process variables consist of volumetric flow rate, contact time and bed height. Results showed that $\mathrm{SiO}_{2}$ compounds in the heterogeneous form with average particle size of $1073 \mathrm{~nm}$, as supported by FT-IR spectrum finding indicating $\mathrm{SiO}_{2}$ signal at wavelength of 958-954 $\mathrm{cm}^{-1}$. Additionally, EDX analysis showed Silica and Oxygen content of $11.88 \%$ and $36.90 \%$, resulting $70 \% \mathrm{CO}_{2}$ adsorption capacity of $0.350 \mathrm{mg} / \mathrm{g}$ at discharge of $5 \mathrm{~L} / \mathrm{min}$, contact time of $40 \mathrm{~min}$, and bed height of $12 \mathrm{~cm}$. Langmuir isotherm model was obtained with $R^{2}$ of $0.998, q_{m}$ of 1.588, and $k_{L}$ of 0.144. Meanwhile, the kinetic model followed a simple first-order prototypical with $\mathrm{R}^{2}$ of $0.952, \mathrm{CO}_{2}$ of 0.260 , and $k_{1}$ of 0.006 .
\end{abstract}

Keywords: adsorption; adsorbent; bottom ash; $\mathrm{CO}_{2}$ gas; fixed-bed column

\section{- INTRODUCTION}

Global warming from climate change has been considered a severe issue in the last decades. Several types of research related to climate change show an increase in the Earth's temperature due to human activities [1]. Various human activities such as deforestation, industrial waste smoke, vehicle smoke, and others have caused greenhouse gas emissions to the atmosphere; hence, solar radiation is trapped and increases the Earth's average temperature [2-3]. Numerous efforts have been developed to absorb carbon dioxide $\left(\mathrm{CO}_{2}\right)$ to decrease the greenhouse gas effect [4]. The Indonesian government is also aware of the issue and commits to reducing greenhouse gas emissions [5]. In the Conference of Parties (COP) 21 on United Nations Framework about Climate
Change (UNFCCC) in Paris, France, 30 November 2015, President Joko Widodo stated Indonesia's commitment to reduce greenhouse gas emissions in the amount of $29 \%$ by nation effort and $41 \%$ through international support until 2030.

Indonesia also has a national action plan to reduce greenhouse gas emissions as in Presidential Decree No. 61 of 2011 on the National Action Plan on Greenhouse Gas Emission and Presidential Decree No. 71 of 2011 on implementing a National Greenhouse Gases Inventory. The inventory shows that industrial activity is one of the primary sources of greenhouse gas (GHG) emissions is $\mathrm{CO}_{2}$ [6-7]. More than $75 \%$ of GHG composition in the atmosphere is $\mathrm{CO}_{2}$. Currently, $\mathrm{CO}_{2}$ concentration has risen from $280 \mathrm{ppm}$ in the pre-industrial period to be 
$400 \mathrm{ppm}$. Meanwhile, the recommended limit is $350 \mathrm{ppm}$. Therefore if $\mathrm{CO}_{2}$ contribution in diverse activities is significantly reduced, then the global warming effect to climate change can be suppressed [8].

Several methods to handle $\mathrm{CO}_{2}$ gas emissions have been reported, including physical and chemical absorption, cryogenic, separation with membrane, microalga bio-fixation, and adsorption [9-10]. Among the mentioned methods, the most commonly applied method is the absorption method using an amine functional group compound, in which a gas component is separated from a gas mixture by passing it through liquid [11-13]. However, there are drawbacks in this separation process like amine mixture degradation due to impurities in the gas phase at low temperature (below $50{ }^{\circ} \mathrm{C}$ ), apparatus corrosion, the extensive energy requirement for regeneration, solvent quality degradation due to impregnation with other products, and amine escape by vaporization [14].

The adsorption method is preferable to the absorption method due to adsorption is more economical, able to remove organic materials, and no poisonous side effects occur [15]. Furthermore, the adsorption method is a promising alternative to adsorb $\mathrm{CO}_{2}$, considering its relatively inexpensive, more straightforward process and no liquid waste produced [4]. Many reports have discussed several types of research on different adsorbents for the adsorption $\mathrm{CO}_{2}$ process, namely activated carbon, zeolite, silica mesopores, alumina, double-layered hydroxide, and metal oxide. A summary of the adsorption capacity reported for employing various types of adsorbents is presented in Table 1.

Biomass and waste-based adsorbent materials are usually preferable for commercial purposes, namely solid waste from palm oil plants, palm shells, and husk [16].
Many plants utilize shell and husk as fuel to boiler producing steam. Palm shell and husk burning liberate ash left at the furnace as solid granules or crust, usually called bottom ash. Bottom ash contains silica $\left(\mathrm{SiO}_{2}\right)$ and alumina $\left(\mathrm{Al}_{2} \mathrm{O}_{3}\right)$, which is the primary content of zeolite. Zeolite has adsorption selectivity $\mathrm{CO}_{2} / \mathrm{N}_{2} 5$ to 10 times higher than carbon-based adsorbent in fixed-bed columns $[3,12,17]$. Bottom ash has the same content as zeolite; hence it can absorb $\mathrm{CO}_{2}$.

Studies on bottom ash-based adsorbents have been done to adsorb heavy metals but are still limited for $\mathrm{CO}_{2}$ adsorption. Currently, the utilization of bottom ash is not optimum and well managed yet. Bottom ash is an issue in the palm oil industry since the storage occupies a large area, increasing annually [18]. Laharto et al. [16] used the synthesis of mesoporous silica from bottom ash waste for $\mathrm{CH}_{4}$ adsorption. The adsorption capacity at a pressure of 1 atm and a temperature of $30{ }^{\circ} \mathrm{C}$ is $0.923 \mathrm{mmol} / \mathrm{g}$. Lira-Zúñiga et al. [17] used biomass combustion ashes on agricultural to $\mathrm{CO}_{2}$ adsorption. The bottom ash sample from the combustion of wheat bran (agricultural biomass) and its pellets showed a higher adsorption capacity for most of the temperatures studied. The pelletized bottom ash reached the maximum adsorption capacity $\left(0.07 \mathrm{mmol} \mathrm{CO}_{2} / \mathrm{g}\right)$, followed by the non-pelletized bottom ash $(0.06 \mathrm{mmol}$ $\mathrm{CO}_{2} / \mathrm{g}$ ).

By considering the above concern, this research is aimed to study the characteristics and capability of bottom ash from the palm oil industry burning in the boiler as adsorbent to adsorb $\mathrm{CO}_{2}$. Adsorption is conducted at the fixed-bed column. Previous studies using this absorbent to absorb $\mathrm{CO}_{2}$ have been done $[5,8,14]$. However, variation of the flow rate and bed height has not been studied yet. Therefore, this research

Table 1. The adsorption capacity of diverse adsorbents

\begin{tabular}{lcccc}
\hline Adsorbent & $\begin{array}{c}\text { Temperature } \\
\left({ }^{\circ} \mathrm{C}\right)\end{array}$ & $\begin{array}{c}\text { Pressure } \\
(\mathrm{atm})\end{array}$ & $\begin{array}{c}\text { Adsorption capacity } \\
(\mathrm{mmol} / \mathrm{g})\end{array}$ & References \\
\hline Activated Carbon & 25 & 1 & 1.202 & {$[13]$} \\
Activated Carbon & 50 & 1 & 0.450 & {$[14]$} \\
Activated Carbon & 25 & 1 & 2.828 & {$[15]$} \\
Zeolite 13 X & 25 & 1 & 4.245 & {$[15]$} \\
Zeolite 4A & 25 & 1 & 3.263 & {$[15]$} \\
\hline
\end{tabular}


focuses on various volumetric flow rates, contact times, and bed heights. Adsorption equilibrium is generally studied through the adsorption isotherm approach [19]. In this study, the Langmuir and Freundlich adsorption equilibrium models were evaluated. The effectiveness of the adsorption in a fixed-bed column using bottom ash as adsorbent is then examined.

\section{- EXPERIMENTAL SECTION}

\section{Materials}

The raw material that was used in this research was bottom ash from boiler burning of Palm Oil Plant PT. Syaukad Sejahtera, Kuta Blang, Gerugok, North Aceh, Indonesia and it was used as adsorbent. The supporting raw material was tapioca flour (SMS Genigel 48 Modified) and distilled water as a mixture for making tapioca glue.

\section{Instrumentation}

The adsorbent is applied at the acrylic pipe as an adsorption column with a $6.4 \mathrm{~cm}$ diameter and $30 \mathrm{~cm}$ length, as shown in Fig. 1, done at a single column. Additional used apparatuses were oven (Memmert UN 30), valve (VG $16 \mathrm{DD}$ ), hot plate (Heidolph C-MAG MS 4), sieve mesh 20 mesh (AMB No 20), adsorbent mold (tube mold stainless steel $1.5 \times 1 \mathrm{~cm}$ ), furnace (FNC-2 BOne Furnace), desiccator, spatula, beaker glass $500 \mathrm{~mL}$, measuring cup $100 \mathrm{~mL}$, porcelain cup, $\mathrm{CO}_{2}$ tube detector from China (HT-2000 $\mathrm{CO}_{2}$ meter), Scanning electron microscope/energy-dispersive X-ray spectroscopy (SEM/EDX, CARL ZEISS type EVO MA 10), X-Ray Diffraction (XRD, Shimadzu XRD-6100), and Fourier Transform Infra-Red spectrophotometer (FT-IR, IR Prestige 21).

\section{Procedure}

The raw palm kernel shell was washed with deionized water several times to remove all traces, such as oil and dirt. Next, the material was dried in an oven with a temperature of $100{ }^{\circ} \mathrm{C}$. The preparation process was initiated by sieving $100 \mathrm{~g}$ of bottom ash using a 20 mesh sieve. Then $15 \mathrm{~g}$ of tapioca flour and $45 \mathrm{~mL}$ of distilled water are heated until they become glue. Furthermore, $100 \mathrm{~g}$ of bottom ash and the glue are mixed and stirred

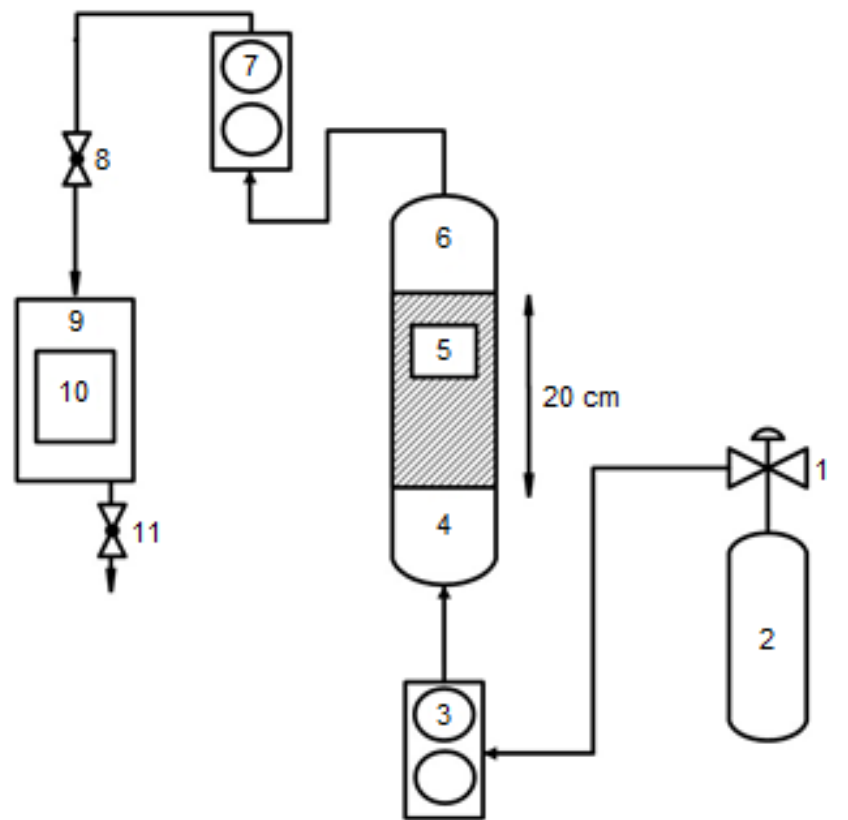

Fig 1. Single column adsorption column diagram of experimental apparatus for fixed-bed adsorption: (1) valve; (2) $\mathrm{CO}_{2}$ gas cylinder; (3) flow meter $\mathrm{CO}_{2}$ in; (4) bottom column adsorption (5) fixed-bed adsorber; (6) top column adsorption; (7) flowmeter $\mathrm{CO}_{2}$ out; (8) valve; (9) box detector gas (10) $\mathrm{CO}_{2}$ analyzer; (11) stop valves

until evenly distributed. Next, the mixture was printed using a $1.5 \mathrm{~cm}$ diameter mold with a thickness of $1 \mathrm{~cm}$ then dry in the oven for $2 \mathrm{~h}$ using a temperature of $105{ }^{\circ} \mathrm{C}$. After that, the mixture was calcinated with a furnace at $600{ }^{\circ} \mathrm{C}$ for $120 \mathrm{~min}$. The adsorbent is then cooled using a desiccator to room temperature and ready for the $\mathrm{CO}_{2}$ absorption process.

The adsorption process was initiated by flowing $\mathrm{CO}_{2}\left(\mathrm{C}_{0}\right) 500 \mathrm{ppm}$ into an adsorption column. First, the bottom ash adsorbent used was placed in a column of $30 \mathrm{~cm}$ and $6.4 \mathrm{~cm}$ in diameter, whereas the height of adsorbent $(\mathrm{Z})$ in a column was varied of $4 \mathrm{~cm}(14 \mathrm{~g}), 8$ $\mathrm{cm}(28)$, and $12 \mathrm{~cm}(42 \mathrm{~g})$. Next, $\mathrm{CO}_{2}$ was flown into a column with flow rates 10,15 , and $20 \mathrm{~L} / \mathrm{min}$ and varied contact times of 10, 20, 30, and $40 \mathrm{~min}$, as shown in Fig. 1. After that, the efficiency and adsorption capacity of $\mathrm{CO}_{2}$ was calculated with the following Eq. (1) and (2) $[5,14]$ :

Efficiency $=\frac{\mathrm{CO}_{2} \text { Initial }-\mathrm{CO}_{2} \text { Final }}{\mathrm{CO}_{2} \text { Initial }} \times 100 \%$ 
Adsorption Capacity $=\frac{\text { Flowrate }\left(\mathrm{CO}_{2} \text { Initial }-\mathrm{CO}_{2 \text { Final }}\right)}{\text { Sample Mass }}$

\section{- RESULTS AND DISCUSSION}

This activation is purposed to switch cations to be $\mathrm{H}^{+}$and release $\mathrm{Al}, \mathrm{Fe}, \mathrm{Mg}$, and other impurities (containing alkaline/alkaline Earth) from the structural grid. Impurities on the adsorbent surface covering active sites of adsorbent can be removed by burning during activation. As a result, the adsorbent structure has a broader area and improves the active site, exposing covered active sites and new active site occurrence. In addition, the surface area specified pores improvement and the active sites enable adsorption capability enhancement. The $\mathrm{CO}_{2}$ adsorption mechanism is shown in Fig. 2.

\section{Adsorbent Characterization}

\section{FT-IR analysis}

FT-IR measurement results in the form of the spectrum before and after adsorption is shown in Fig. 3. Peaks appeared identifies several functional groups. The peak at wave number $3387-3010 \mathrm{~cm}^{-1}$, stretching vibration from the $\mathrm{OH}$ group, showed water in the sample. The peak affirms this interpretation at $1629-1504 \mathrm{~cm}^{-1}$ from the -OH group's bending vibration. The peak at $958-954 \mathrm{~cm}^{-1}$ showed the $\mathrm{Si}-\mathrm{O}-\mathrm{Si}$ group that identified silica in the bottom ash. The other peaks are at $812 \mathrm{~cm}^{-1}$, showing the $\mathrm{Al}-\mathrm{O}-\mathrm{Al}$ group of alumina and at $505 \mathrm{~cm}^{-1}$ for the $\mathrm{Si}-\mathrm{O}-$ $\mathrm{Al}$ adsorption band. Finally, $\mathrm{CO}_{2}$ gas adsorption is shown at $2337 \mathrm{~cm}^{-1}$. This result is suitable to adsorbing peak reported by other researchers who showed adsorbing band of $\mathrm{CO}_{2}$ in the range of $2500-2000 \mathrm{~cm}^{-1}$ [16-19].

\section{SEM/EDX analysis}

SEM/EDX Analysis was to comprehend the bottom ash adsorbent characteristic before and after adsorption. SEM testing was applied to observe the morphology or material surface description and EDX to analyze the adsorbent's material components or atomic composition. The SEM analysis result can be seen in Fig. 3 and 4.

Fig. 4 shows bottom ash SEM results before adsorption that had been physically activated with activation temperature $600{ }^{\circ} \mathrm{C}$, causing reduction of water molecules and organic materials from pore channels, increasing the number of pore volume and adsorbent surface area. The average pore size is $767 \mathrm{~nm}$.

Fig. 4 shows the adsorbent SEM after adsorption, it can be seen that the pore diameter became varied, and the pore hollows became tighter with an average diameter

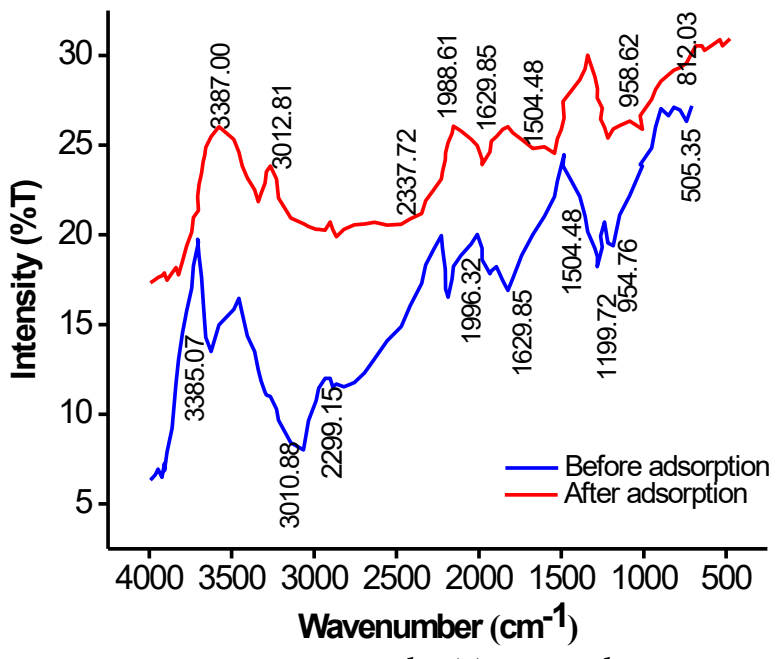

Fig 3. Bottom ash FT-IR result

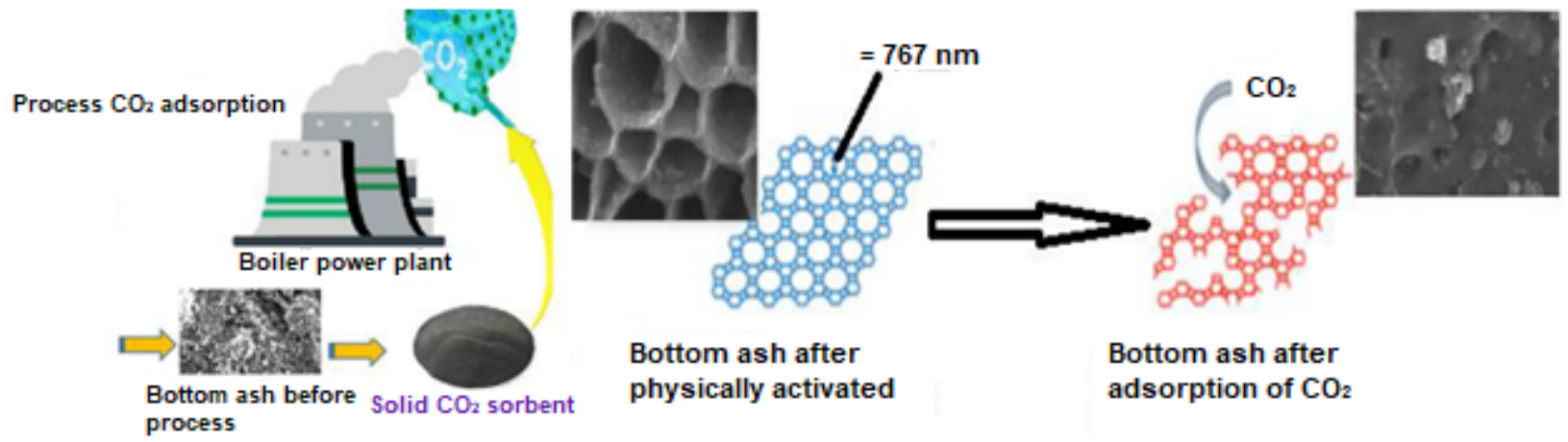

Fig 2. Carbon dioxide adsorption mechanism 

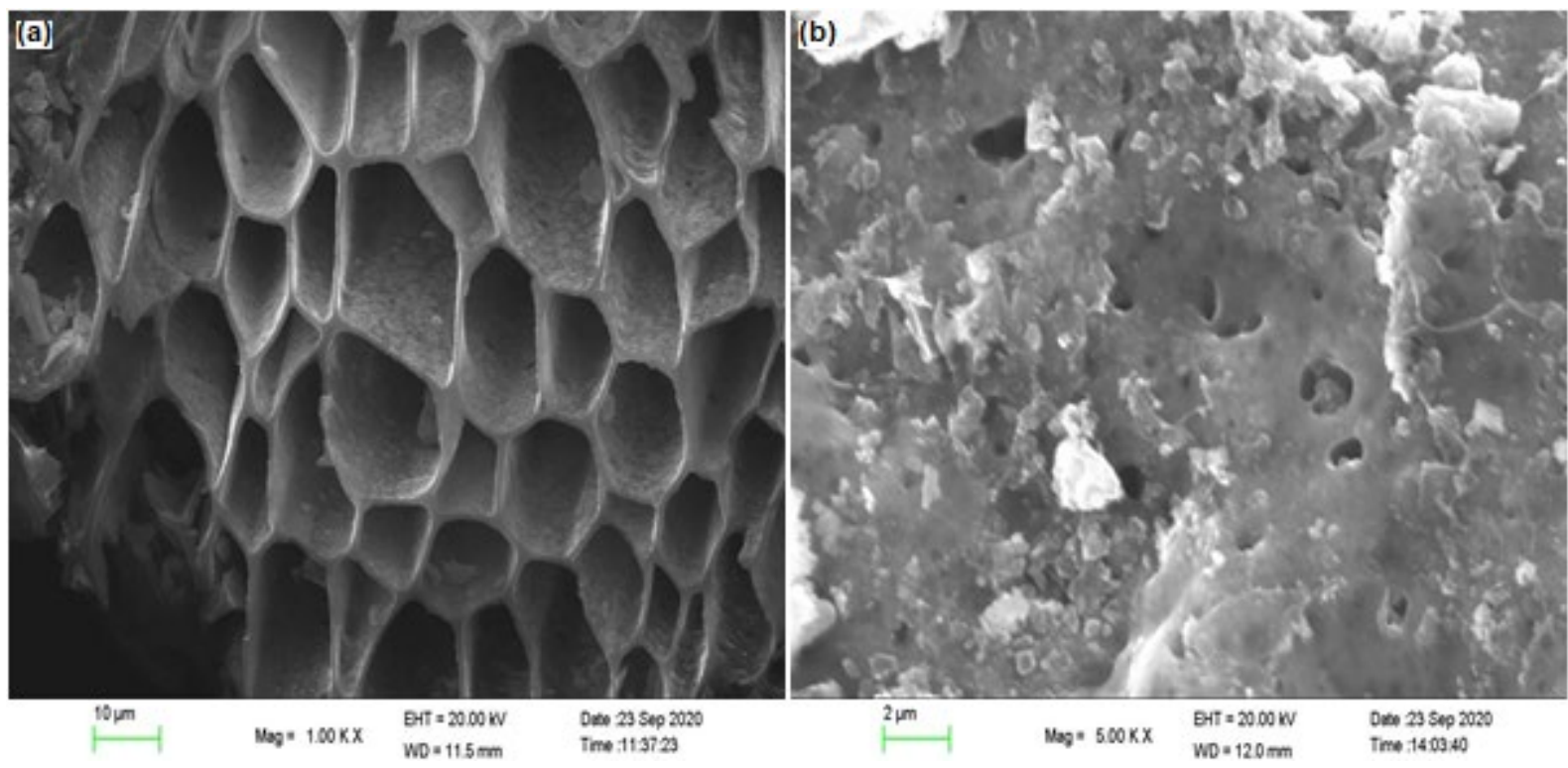

Fig 4. Adsorbent SEM result (a) before and (b) after adsorption

after adsorption $564 \mathrm{~nm}$. The pore diameter became hollows because $\mathrm{CO}_{2}$ gas was adsorbed so that adsorbent pores were covered and bound. SEM analysis shows that the adsorbent based on the bottom ash of the palm oil plant had a pore size of more than $50 \mathrm{~nm}$. According to the size, the adsorbent is classified as macropores typed adsorbent and suitable as reported by other literature stating that POFA has three types; macropore ( $55 \mathrm{~nm}$ and $>55 \mathrm{~nm}$ ), mesopore $(7 \mathrm{~nm}$ and $8 \mathrm{~nm})$, and micropore $(<1 \mathrm{~nm})$ [2].

The bottom ash EDX analysis result is shown in Fig. 5 and Table 1. Table 1 shows that bottom ash components are $\mathrm{C}, \mathrm{O}, \mathrm{Mg}, \mathrm{Al}, \mathrm{Si}, \mathrm{P}, \mathrm{S}, \mathrm{K}, \mathrm{Ca}$, and Fe elements. The highest composition components were carbon, oxygen, and silica, identifying that bottom ash has silica oxide $\left(\mathrm{SiO}_{2}\right)$ as an adsorbent composing component. The EDX analysis result fits with the XRD characteristics result and demonstrates the same composing elements. $\mathrm{SiO}_{2}$ is proven to have good activity in the adsorption process.

Effect of flow rate on the breakthrough curve. The breakthrough curve for a column was determined by plotting the ratio of $\mathrm{C}_{\mathrm{t}} / \mathrm{C}_{0}$ against time, as shown in Fig. 5 . The column was found to perform effectively at the lowest rate of $5 \mathrm{~L} / \mathrm{min}$. Previously, breakthrough and exhaustion were reached at a flow rate of 5 to $20 \mathrm{~L} / \mathrm{min}$. The column
Table 1. Adsorbent EDX analysis results before adsorption and after adsorption

\begin{tabular}{llccc}
\hline & & \multicolumn{3}{c}{ Atom (\%) } \\
\cline { 3 - 5 } No & Element & $\begin{array}{c}\text { Bottom } \\
\text { ash }\end{array}$ & $\begin{array}{c}\text { Before } \\
\text { Adsorption }\end{array}$ & $\begin{array}{c}\text { After } \\
\text { Adsorption }\end{array}$ \\
\hline 1 & $\mathrm{C}$ & 40.35 & 45.77 & 69.02 \\
2 & $\mathrm{O}$ & 36.29 & 36.90 & 23.63 \\
3 & $\mathrm{Mg}$ & 1.21 & 1.01 & 0.90 \\
4 & $\mathrm{Al}$ & 0.42 & 0.36 & 0.10 \\
5 & $\mathrm{Si}$ & 7.68 & 11.88 & 1.84 \\
6 & $\mathrm{P}$ & 0.63 & 0.55 & 0.31 \\
7 & $\mathrm{~S}$ & 0.56 & - & 0.19 \\
8 & $\mathrm{~K}$ & 0.39 & 1.88 & 1.79 \\
9 & $\mathrm{Ca}$ & 7.47 & 1.36 & 1.63 \\
10 & $\mathrm{Fe}$ & 0.44 & 0.28 & 0.07 \\
11 & $\mathrm{Cl}$ & 0.42 & - & - \\
\hline
\end{tabular}

breakthrough time $\left(\mathrm{C}_{\mathrm{t}} / \mathrm{C}_{0}=0.05\right)$ was reduced from 150 min to $10 \mathrm{~min}$ by flow rate was increasing between 5 to $20 \mathrm{~L} / \mathrm{min}$. The decline of contact time has limited the contact of $\mathrm{CO}_{2}$ against bottom ash $\mathrm{CO}_{2}$ did not have sufficient time to diffuse into the pores of bottom ash at a higher flow rate, and $\mathrm{CO}_{2}$ was out of the column before equilibrium. Similar results were found in the adsorption of $\mathrm{CO}_{2}$ of the fixed-bed system in the column [20]. 


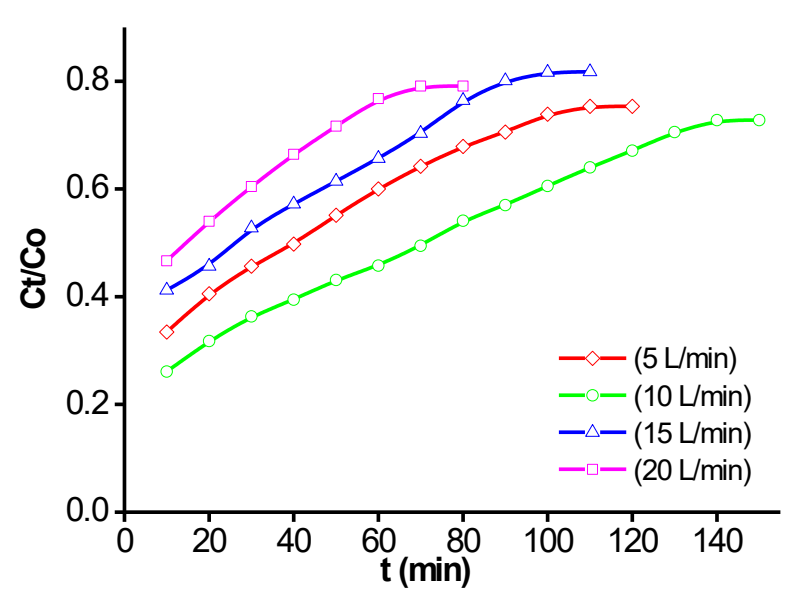

Fig 5. Breakthrough curves: the effect of flow rate on $\mathrm{CO}_{2}$ adsorption $\left(\mathrm{C}_{0}=500 \mathrm{mg} / \mathrm{L}\right.$ and $\left.\mathrm{Z}=12 \mathrm{~cm}\right)$

Effects of flow rate, contact time, and bed height to $\mathrm{CO}_{2}$ adsorption efficiency and adsorption capacity. $\mathrm{CO}_{2}$ flow rate and bed height have significant effects on adsorption efficiency. Fig. 6 shows that a greater flow rate yielded a lower adsorption efficiency. The highest adsorption efficiency was at $10 \mathrm{~L} / \mathrm{min}$ flow rate and bed height $12 \mathrm{~cm}$. As the flow rate of $\mathrm{CO}_{2}$ is getting higher, the contact time between $\mathrm{CO}_{2}$ and adsorbent becomes shorter, thus the less $\mathrm{CO}_{2}$ adsorption efficiency percentage [20]. These results are proportional to reported research from several works of literature that the flow rate significantly affects the adsorption process [21].

Contact time and collision are essential factors in adsorption. According to collision theory, the rate of reaction is the number of collisions in the time unit. The longer the contact time, the more collisions occur, hence the faster chemical reaction to reach equilibrium. The duration needed to achieve adsorption equilibrium are different. The type of interaction between adsorbent and adsorbate has influenced the result. The influence of contact time on the efficiency of adsorbent adsorbs $\mathrm{CO}_{2}$ gas is shown in Fig. 7.

Fig. 7 shows the adsorption contact time started from 10 to $40 \mathrm{~min}$. The best contact time took place at 40 min alongside the highest adsorption efficiency of 70\% at $12 \mathrm{~cm}$ of bed height. The ability of the adsorbent declined after the twentieth minute implied that the adsorbent was saturated after that period because the adsorbent surface has a certain number of active adsorption sites. The

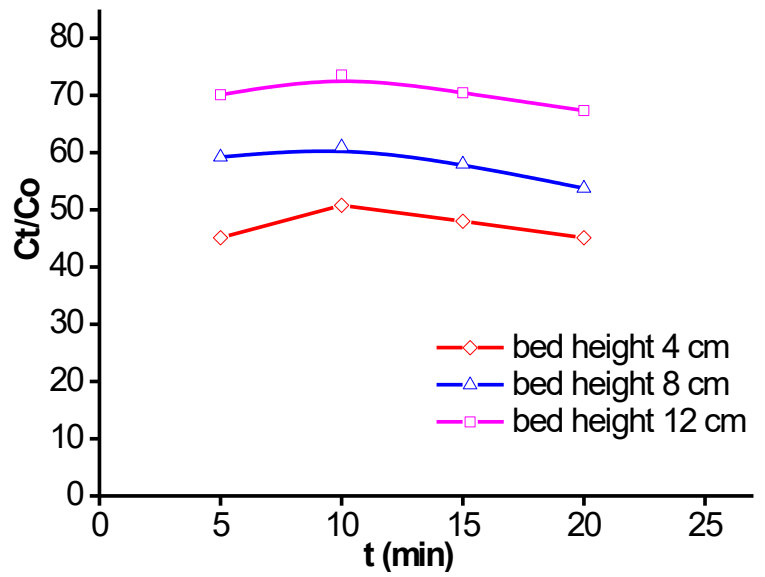

Fig 6. Correlation between flow rate and $\mathrm{CO}_{2}$ adsorption efficiency graph at different bed height

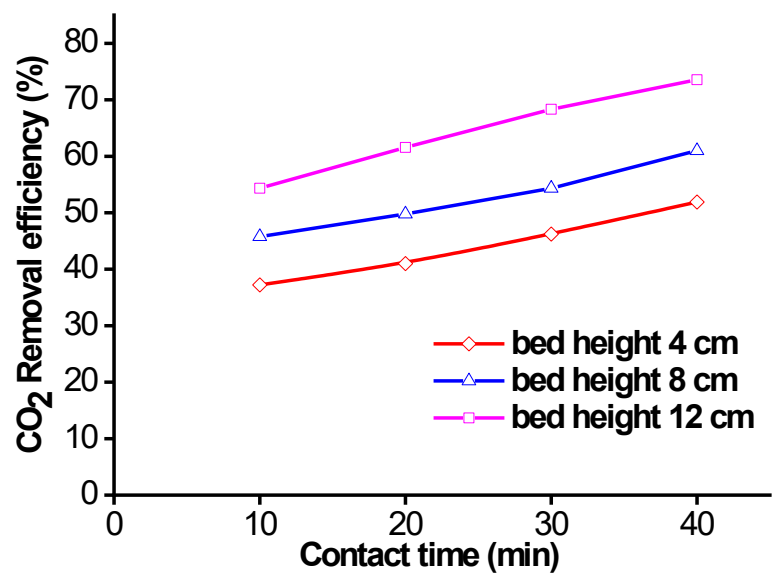

Fig 7. Correlation between contact time and $\mathrm{CO}_{2}$ adsorption efficiency graph at different bed heights

number of active sites is proportional to the adsorbent surface area. The active site is the adsorbate attaching media on the adsorbent surface. After some time, the active site becomes saturated, and desorption occurs, the detachment of adsorbed molecules on the surface. Thus, after the twentieth-minute desorption happened in which the adsorbed molecules were detached, the $\mathrm{CO}_{2}$ composition increased, or $\mathrm{CO}_{2}$ adsorption efficiency declined.

Effects of contact time and bed height to adsorption capacity. Determination of adsorption capacity was done to understand the bottom ash capability in adsorbing $\mathrm{CO}_{2}$. The effects of contact time and bed height on adsorption capacity are shown in Fig. 8. 


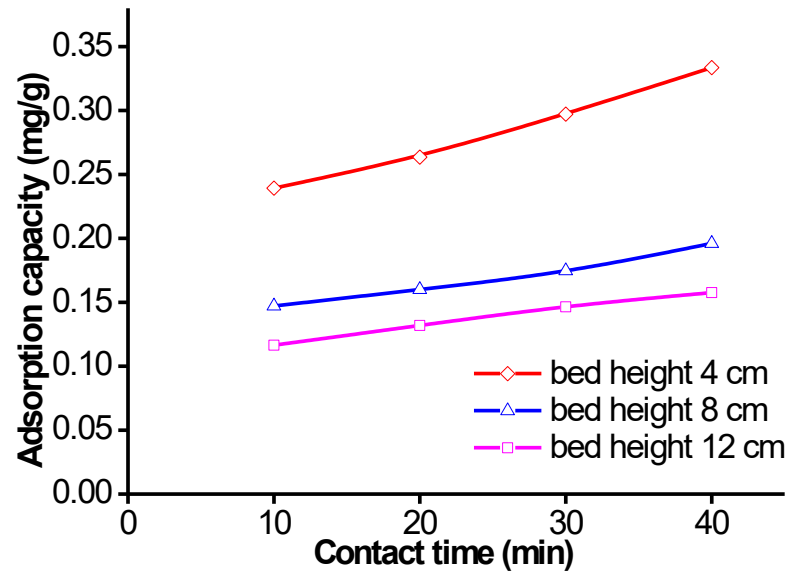

Fig 8. Contact time to adsorption capacity relation graphs at different bed height

Fig. 8 shows that the adsorption capacity increases as the bed height increases. The increment can be correlated with adsorbent surface area and its active sites. The higher bed height means the larger surface area of adsorbent to more $\mathrm{CO}_{2}$ adsorption capacity [22]. The highest adsorption capacity was $0.350 \mathrm{mg} / \mathrm{g}$ was achieved at a contact time of $40 \mathrm{~min}$ and bed height $4 \mathrm{~cm}$. At the beginning of contact time, the adsorption process took place at a fast rate since the active site of the adsorbent was still large so that the binding of adsorbate molecules frequency became sufficiently high. As the contact time increases, the amount of adsorbate adsorbed to the adsorbent surface becomes higher until the equilibrium point is reached. Excessive contact time between adsorbent and adsorbate causes adsorbent to be saturated and detached from adsorbate [23-25].

\section{Isothermal Adsorption}

Adsorption equilibrium, which is generally studied through the adsorption isotherm approach, is an essential foundation for understanding an adsorption process, especially for finding out how many adsorbate molecules can be adsorbed by a porous material. The adsorption equilibrium model for pure components was based on Langmuir's [14-15] theory about monolayer adsorption on an ideal surface. Langmuir and Freundlich's models are used to represent data adsorption balance. Langmuir's model assumes that the adsorbent surface is homogeneous where the constant energy adsorption on the entire surface of the adsorbent. This model also assumes that the adsorption is localized, and each location can only accommodate one molecule or atom. Adsorption isotherms Freundlich and Langmuir of $\mathrm{CO}_{2}$ are shown in Table 2. A suitable isotherm model for the equilibrium curve must be determined to optimize the design of the sorption system for the absorption of $\mathrm{CO}_{2}$ in bottom ash. In this study, the balance model that has been analyzed is Langmuir and Freundlich. The predicted value of the model and the experimental data was validated by comparing the experimental adsorption capacity with the adsorption capacity estimated by this model via a coefficient of determination $\left(\mathrm{R}^{2}\right.$, value close to or equal to 1) [19-20], shown in Fig. 9.

Table 2. Parameter isotherm Langmuir and Freundlich for adsorption $\mathrm{CO}_{2}$ in bottom ash

\begin{tabular}{lccc}
\hline Type & Parameters & Unit & $\begin{array}{l}\text { Equation } \\
\text { non-Linear }\end{array}$ \\
\hline Langmuir & 1.588 & $\mathrm{mg} / \mathrm{g}$ & $\mathrm{q}=\frac{\mathrm{q}_{\mathrm{m}} \mathrm{k}_{\mathrm{L}} \mathrm{C}_{\mathrm{e}}}{1+\mathrm{k}_{\mathrm{L}} \mathrm{C}_{\mathrm{e}}}$ \\
$\mathrm{q}_{\mathrm{m}}$ & 0.144 & - & \\
$\mathrm{k}_{\mathrm{L}}$ & 0.998 & - & \\
$\mathrm{R}^{2}$ & & & \\
\hline Freundlich & 6.519 & - & $\frac{1}{\frac{\mathrm{n}}{\mathrm{n}}}$ \\
$\mathrm{k}_{\mathrm{F}}$ & -1.812 & - & $\mathrm{q}=\mathrm{k}_{\mathrm{f}} \mathrm{C}_{\mathrm{e}}$ \\
$\mathrm{n}$ & 0.815 & - & \\
$\mathrm{R}^{2}$ & & \\
\hline
\end{tabular}

where: $\mathrm{q}$ is the amount of adsorbed $\mathrm{CO}_{2}$ per unit weight of bottom ash at equilibrium, and $\mathrm{Ce}_{\mathrm{e}}$ is the unadsorbed $\mathrm{CO}_{2}$ concentration in effluent at equilibrium $(\mathrm{mg} / \mathrm{L}) . \mathrm{k}_{\mathrm{L}}$ is the Langmuir equilibrium constant, $\mathrm{q}_{\mathrm{m}}$ is the amount of $\mathrm{CO}_{2}$ adsorbed with monolayer coverage, $\mathrm{k}_{\mathrm{F}}$ is the Freundlich constant, and $\mathrm{n}$ is the Freundlich exponent

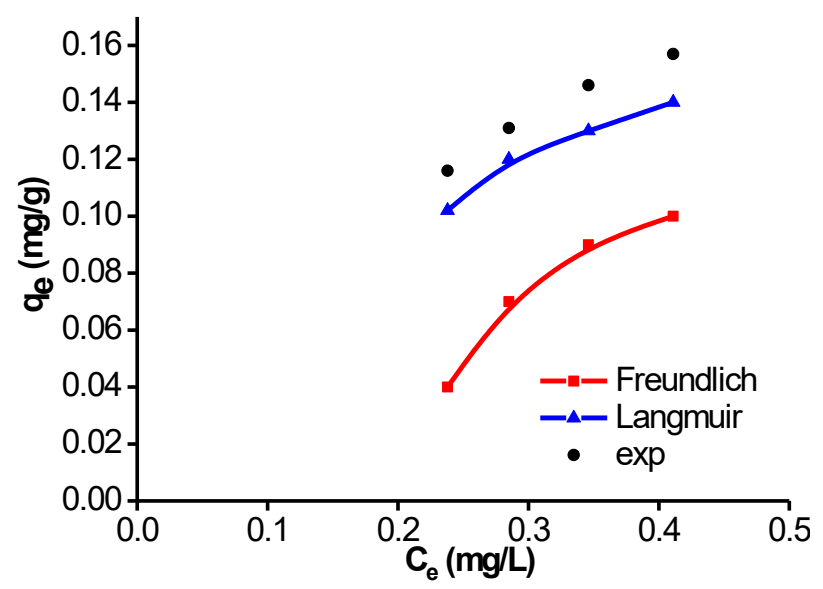

Fig. 9. Contact time to adsorption capacity relation graphs at different bed height 
Table 3. Parameter kinetic models for adsorption $\mathrm{CO}_{2}$ in bottom ash

\begin{tabular}{lcll}
\hline Kinetic models & Parameters & Unit & Equation non-Linear \\
\hline Simple first-order & & & \\
$\mathrm{k}_{1}$ & 0.006 & $\mathrm{~min}^{-1}$ & $\mathrm{C}_{\mathrm{t}}=\mathrm{C}_{0} \mathrm{e}^{\mathrm{k}_{1} \mathrm{t}}$ \\
$\mathrm{C}_{0}$ & 0.260 & $\mathrm{mg} / \mathrm{L}$ & \\
$\mathrm{R}^{2}$ & 0.952 & & \\
\hline Pseudo-second-order $\mathrm{k}_{2}$ & & & \\
$\mathrm{k}_{2}$ & 0.043 & $\mathrm{mg}^{-1} \mathrm{~min}^{-1}$ & $\frac{\mathrm{dq}_{\mathrm{t}}}{\mathrm{dt}}=\mathrm{k}_{2}\left(\mathrm{q}_{\mathrm{e}}-\mathrm{q}_{\mathrm{t}}\right)^{2}$ \\
$\mathrm{q}_{\mathrm{e}}$ & 0.055 & $\mathrm{mg} / \mathrm{g}$ & \\
$\mathrm{R}^{2}$ & 0.903 & & \\
\hline
\end{tabular}

Fig. 9 shows that the Langmuir model is very close to the experimental data as seen from the $\mathrm{R}^{2}$ constant, which is 0.998 . It can be explained that bottom ash is an adsorbent that absorbs $\mathrm{CO}_{2}$ in the monolayer at a pressure of $1 \mathrm{~atm}$ and a temperature of $25^{\circ} \mathrm{C}$.

\section{Kinetic Studies}

An analysis of the kinetic adsorption process is a helpful tool to estimate the time of residence for the adsorption process to complete and determine adsorption dynamics and its performance in the industrial scale of a fixed bed or flow-through system. Thus, the simple firstorder and pseudo-second-order models were performed in this study. The kinetic parameters of these models are shown in Table 3. Comparing the values of determination coefficients as stated in Table 3, the simple first-order model gives a better fit than the pseudo-second-order, with an $\mathrm{R}^{2}$ value is 0.952 [20-23].

\section{- CONCLUSION}

A similar result was supported with FT-IR spectrum at the wavelength $958-954 \mathrm{~cm}^{-1}$, showing that the Si-OSi group and EDX analysis show silica and oxygen atomic contents were $11.88 \%$ and $36.90 \%$, respectively. The $\mathrm{CO}_{2}$ adsorption efficiency was $70 \%$, while adsorption capacity was $0.350 \mathrm{mg} / \mathrm{g}$ at $12 \mathrm{~cm}$ bed height operating condition. The isotherm model obtained in this study was Langmuir, while the kinetic model was simple first order. Therefore, bottom ash can be used to capture $\mathrm{CO}_{2}$ emissions.

\section{- ACKNOWLEDGMENTS}

The author thanks the ministry of Malikussaleh
University for financial support through the research project PNBP, No. 530/UN45/KPT/2021.

\section{- REFERENCES}

[1] Abunowara, M., Bustam, M.A., Sufian, S., and Eldemerdash, U., 2016, Description of carbon dioxide adsorption and desorption onto Malaysian coals under subcritical condition, Procedia Eng., 148, 600-608.

[2] Silva, J.A.C., Schumann, K., and Rodrigues., A.E., 2012, Sorption and kinetics of $\mathrm{CO}_{2}$ and $\mathrm{CH}_{4}$ in binderless beads of $13 \mathrm{X}$ zeolite, Microporous Mesoporous Mater., 158, 219-228.

[3] Kongnoo, A., Tontisirin, S., Worathanakul, P., and Phalakornkule, C., 2017, Surface characteristics and $\mathrm{CO}_{2}$ adsorption capacities of acid-activated zeolite 13X prepared from palm oil mill fly ash, Fuel, 193, 385-394.

[4] Chen, S.J., Zhu, M., Fu, Y., Huang, Y.X., Tao, Z.C., and Li, W.L., 2017, Using 13X, LiX, and LiPdAgX zeolites for $\mathrm{CO}_{2}$ capture from post-combustion flue gas, Appl. Energy, 191, 87-98.

[5] Hauchhum, L., and Mahanta, P., 2014, Carbon dioxide adsorption on zeolites and activated carbon by pressure swing adsorption in a fixed bed, Int. J. Energy Environ. Eng., 5 (4), 349-356.

[6] Girimonte, R., Formisani, B., and Testa, F., 2017, Adsorption of $\mathrm{CO}_{2}$ on a confined fluidized bed of pelletized 13X zeolite, Powder Technol., 311, 9-17.

[7] Campo, M.C., Ribeiro, A.M., Ferreira, A.F.P., Santos, J.C., Lutz, C., Loureiro, J.M., and Rodrigues A.E., 2016, Carbon dioxide removal for methane 
upgrade by a VSA process using an improved 13X zeolite, Fuel Process. Technol., 143, 185-194.

[8] Ridha, F.N., Manovic, V., Macchi, A., and Anthony, E.J., 2015, $\mathrm{CO}_{2}$ capture at ambient temperature in a fixed bed with $\mathrm{CaO}$-based sorbents, Appl. Energy, 140, 297-303.

[9] Gouveia, L.G.T., Agustini, C.B., Perez-Lopez, O.W., and Gutterres, M., 2020, $\mathrm{CO}_{2}$ adsorption using solids with different surface and acid-base properties, $J$. Environ. Chem. Eng., 8 (4), 103823.

[10] Regufe, M.J., Ribeiro, A.M., Ferreira, A.F.P., and Rodrigues, A., 2019, " $\mathrm{CO}_{2}$ storage on zeolites and other adsorbents" in Nanoporous Materials for Gas Storage, Green Energy and Technology, Eds. Kaneko, K., and Rodríguez-Reinoso, F., Springer, Singapore, 359-381.

[11] Gil, A., Arrieta, E., Vicente, M.A., and Korili, S.A., 2018, Synthesis and $\mathrm{CO}_{2}$ adsorption properties of hydrotalcite-like compounds prepared from aluminum saline slag wastes, Chem. Eng. J., 334, 1341-1350.

[12] Bezerra, D.P., da Silva, F.W.M., de Moura, P.A.S., Sousa, A.G.S., Vieira, R.S., Rodriguez-Castellon, E., and Azevedo, D.C.S., 2014, $\mathrm{CO}_{2}$ adsorption in aminegrafted zeolite 13X, Appl. Surf. Sci., 314, 314-321.

[13] Bezerra, D.P., Silva, F.W.M., de Moura, P.A.S., Sousa, A.G.S., Vieira, R.S., Rodriguez-Castellon, E., Azevedo, D.C.S., 2014, Adsorption of $\mathrm{CO}_{2}$ on amine grafted activated carbon, Adsorpt. Sci. Technol., 32, 141-151.

[14] Dantas, T.L.P., Luna, F.M.T., Silva, I.J., de Azevedo, D.C.S., Grande, C.A., Rodrigues, A.E., and Moreira, R.F.P.M., 2011, Carbon dioxide-nitrogen separation through adsorption on activated carbon in a fixed bed, Chem. Eng. J., 169 (1-3), 11-19.

[15] Laharto, P.B.F., Anggraini, A.P.K., Fauzany, U.S., Kurniawan, R.Y., and Endang, P.S., 2019, Synthesis of mesoporous silica from bottom ash waste for $\mathrm{CH}_{4}$ adsorption, Mater. Sci. Forum, 964, 130-135.

[16] Liu, Q., He, P., Q, Qian, X., Fei, Z., Zhang, Z., Chen, X., Tang, J., Cui, M., Qiao, X., and Shi, Y., 2017, Enhanced $\mathrm{CO}_{2}$ adsorption performance on hierarchical porous ZSM-5 zeolite, Energy Fuels, 31 (12), 13933-13941.

[17] Lira-Zúñiga， S., Sáez-Navarrete, C., Rodríguez-
Córdova, L., Herrera-Zeppelin, L., and HerreraUrbina, R., 2016, $\mathrm{CO}_{2}$ adsorption on agricultural biomass combustion ashes, Maderas, Cienc. Tecnol., 18 (4), 607-616.

[18] Lee, S.Y., and Park, S.J., 2015, A review on solid adsorbents for carbon dioxide capture, J. Ind. Eng. Chem., 23, 1-11.

[19] Sylvia, N., Mutia, R., Malasari, M., Dewi, R., Bindar, Y., and Yunardi, Y., 2019, A computational fluid dynamic comparative study on $\mathrm{CO}_{2}$ adsorption performance using activated carbon and zeolite in a fixed bed reactor, IOP Conf. Ser.: Mater. Sci. Eng., 536, 012042.

[20] Yoro, K.O., Singo, M., Mulopo, J.L., and Daramola, M.O., 2017, Modelling and experimental study of the $\mathrm{CO}_{2}$ adsorption behaviour of polyaspartamide as an adsorbent during post-combustion $\mathrm{CO}_{2}$ capture, Energy Procedia, 114.

[21] Lakapu, M.M., and Widiastuti, N., 2017, Synthesis of zeolite-X supported on kapok fiber for $\mathrm{CO}_{2}$ capture material: Variation of immersion time during fiber activation, Indones. J. Chem., 17 (3), 471-476.

[22] Haider, M.B., Jha, D., Sivagnanam, B.M., and Kumar, R., 2018, Thermodynamic and kinetic studies of $\mathrm{CO}_{2}$ capture by glycol and amine-based deep eutectic solvents, J. Chem. Eng. Data, 63 (8), 2671-2680.

[23] Ghazali, Z., Yarmo, M.A., Hassan, N.H., Teh, L.P., and Othaman, R., 2020, New green adsorbent for capturing carbon dioxide by choline chloride: Urea-confined nanoporous silica, Arabian J. Sci. Eng., 45 (6), 4621-4634.

[24] Wardani, A.R.K., and Widiastuti, N., 2016, Synthesis of zeolite-X supported on glasswool for $\mathrm{CO}_{2}$ capture material: Variation of immersion time and $\mathrm{NaOH}$ concentration at glasswool activation, Indones. J. Chem., 278, 16 (1), 1-7.

[25] Minzatu, V., Adina, N., Davidescu, C.M., Duda, C.S., Ciopec, M., Duteanu, N., Negrea, P., Seiman, D.D., and Pascu, I., 2018, Arsenic adsorption into the fixed bed column from drinking groundwater, WIT Trans. Ecol. Environ., 228, 101-110. 